\title{
O Riso e o Medo Tupi
}

\author{
Leif Grünewald ${ }^{1}$
}

Universidade Federal Fluminense, Rio de Janeiro, Brasil E-mail: leif_grunewald@yahoo.co.uk. 


\section{Resumo}

Neste ensaio pretende-se realizar um balanço breve sobre as situações e encontros que amedrontam os índios ou lhes provocam o riso a partir de uma investigação do tema nos estudos etnográficos sobre os Aché, os Yudjá e os Araweté com fins de mapear a variação das descrições indígenas sobre o tema desses encontros para reaproximá-los, no fim, de ideias importadas da filosofia da diferença de Gilles Deleuze.

Palavras-chave: Amazônia. Riso. Medo. Exterior.

\section{Abstract}

This essay proposes a quick and critical overview of those situations which Amerindians fear and those which make them laugh, as elaborated in Aché, Yudjá and Arawete ethnographies, to relate it to some ideas of Gilles Deleuze's philosophy, which I consider important theoretical tools in achieving this purpose.

Keywords: Amazonia. Laughter. Fear. Outside. 


\section{Introdução}

耳 ste ensaio é motivado por um interesse etnográfico naquelas $\amalg$ situações que, como se exprimiram Clastres (2003) e Viveiros de Castro (2012), tanto divertem quanto amedrontam os índios. Nesse sentido, seria possível dizer que seu tema principal são aqueles encontros inoportunos com os jaguares ou com os espíritos e outras formas não humanas de alteridade, assim como o medo ou as risadas que os xamãs provocam nos índios; os acessos de raiva de uma pessoa humana ou os Brancos - também por sua alteridade radical. O meu método aqui consiste, portanto, em fundir alguns aspectos do riso e do medo tal como apresentados em algumas etnografias sobre povos falantes de línguas do tronco linguístico Tupi com a argumentação de Gilles Deleuze $(1983 ;$ 1990; 1991) sobre regimes perceptivos e sua distinção entre afetos e perceptos, usando como gancho o fio da relação entre um sujeito e algo de fora que ultrapassa sua percepção e revela-se, nesse movimento, uma espécie de paisagem não humana da natureza que por vezes pode acabar por levá-lo, no golpe de descentrar sua percepção, a ser atravessado por um devir não humano.

Para explorar essas questões, senti-me, devo confessar, obrigado a visitar alguma parte da literatura etnográfica sobre alguns povos amazônicos de maneira que pudesse cartografar alguns aspectos do riso e do medo e do problema da diferença nas cosmopolíticas ${ }^{2}$ indígenas da Amazônia. A escolha por uma etnografia ou por outra se deveu, em parte, a uma espécie de arbitrário afetivo - escolhi dentre aquelas que me impressionam muito - e, em parte, ao fato das que escolhi terem me facilitado a percepção de dimensões de regimes de diferença e das potências que permitiriam a própria diferença nestes 
sistemas sociocosmológicos. Nesse caso, acabei optando por enfatizar particularmente as etnografias sobre grupos falantes de línguas Tupi, especialmente as etnografias Aché por Clastres (1995; 2003), Yudjá por Lima $(1995 ; 2005)$ e Araweté por Viveiros de Castro (1986). Mas essa escolha também se deve, por outro lado, a um arbitrário linguístico a delimitação do tronco linguístico Tupi - bem como às ressonâncias que esses trabalhos possuem (aos meus olhos, pelo menos) uns com os outros, confiante de que todos os três tenham algo de interessante a dizer a respeito desses acontecimentos que amedrontam os índios ou os fazem gargalhar.

Mas há, como já mencionei, algo mais do que pretendo aqui. Minha intenção também será criar uma zona de vizinhança com o pensamento de Gilles Deleuze, uma vizinhança entre o tema dos encontros entre humanos e seres que ocupam outras posições de alteridade - o tema da diferença, portanto - e os temas que Deleuze argumentou a favor das ideias de "Imagem-Movimento" de "Imagem-Tempo" estão atrelados, segundo este autor, a uma dimensão do "fora", do "intole-

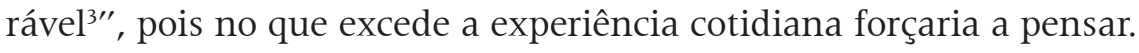
Lisa Åkervall (2008) - que se propôs a pensar e a explicitar a relação entre os livros de cinema de Gilles Deleuze e suas intervenções mais gerais sobre as noções de afeto e de afecção - levantou uma série de finos apontamentos sobre a relação entre esta dimensão "exterior" e "intolerável" e o conceito de afeto. Foram suas ponderações que aguçaram minha atenção ao ler novamente Deleuze e a ela mesma a partir de um ponto de vista não cinematográfico. Um comentário interessante e argutamente formulado pela autora já no início de seu texto não deixa, de fato, de provocar inquietação:

Para a noção de experiência cinematográfica enquanto uma experiência do "além", um excesso de experiência bem como uma experiência de excesso, o conceito de afeto é de importância fundamental. Já a noção de afeto que Deleuze propõe em seus livros sobre o cinema é como mostrarei - aquela de um afeto que transcende a experiência ordinária e faz precipitar o pensamento. (Åkervall, 2008, p. 1, tradução minha) 
Seria a natureza do problema levantado por Deleuze apenas cinematográfica? Seria o cinema o único "cenário" propício a se pensar uma noção de afeto que transcende a experiência ordinária e, nesse movimento, força o pensamento? Voltarei a esse ponto na segunda parte deste ensaio, pois procurarei mostrar como a ideia de que os afetos - não sendo nem afecções, nem sentimentos - e os perceptos sobrepassam os poderes daqueles que são atravessados por ele, desarticulando os regimes perceptivos normais e, representando a si mesmo e transcendendo toda a experienciação, são articuláveis ou não em outros contextos que não o cinematográfico. Vou abordar agora o problema de um ângulo etnográfico.

\section{Da Imanência do Outro: onças, brancos, caçadas e espíritos}

Começarei trazendo, à memória do leitor ou da leitora, duas falas muito singulares que provêm de Jyvukugi, o grande "chefe" dos Aché Gatu, que Clastres considerava como um homem yma chija, uma natureza forte. (1) Enfastiado com a falta de vocabulário para responder às indagações de Clastres ou rabugento pela dificuldade de formular suas questões, Jyvukugi responderia com bastante espanto a uma indagação do antropólogo (Clastres, 1995, p. 237) que se exprimia assim: "- Suponha que eu seja uma Aché. O que eu faço nesse caso?". Retrucaria, então, Jyvukugi, com o seguinte: “- Teeeh! Você é um Aché, você. - Não! Absolutamente! Faço de conta que sou!". Ora, mas de certo não só espanto. Jyvukugi, diferentemente de Krybyragi - reputado por Clastres responder a tudo sempre com muita clareza - explode de rir: a indagação de Clastres não poderia ser-lhe, senão, bastante cômica. Pois bem. Se Jyvukugi não parece ser o mais "colaboracionista'"dentre os Aché Gatu com os Brancos, isso se dá, provavelmente, por sua recusa altiva de compactuar com os beeru. Jyvukugi bem os conhece (foi constrangido outrora a viver com eles) e, por isso, não deseja que lhe constranjam a fazê-lo novamente.

Bem, mas é fato que dos beeru não se ri apenas. Quando o caso é outro e são os beeru que riem muito alto sob a espreita dos índios, o pensamento indígena recheia-se de descontentamento sem que nada pudesse ser feito pelos Aché. Ora, se os Brancos são temíveis, o mesmo 
poderia ser dito de seus aliados, creditados serem naturalmente violentos por excelência, os baigi, os cães, que com seus uivos potentes, latidos que podem ser escutados de longe e sua obstinação em seguir a pista dos Aché quando a havia farejado enchem os índios de horror, fazendo com que os homens Aché, bravos em afrontar jaguares munidos apenas de arco e flecha, se ponham a correr como mulheres ao menor sinal da presença dos baigi.

Misto de riso e temor? Bravura e sabedoria? Não se saberia. De fato, como apontou Clastres, o que fazer com um Machitara ou como prever as reações de um inimigo próximo/familiar irõiangi não era nenhuma novidade para os Aché, mas o que fazer com os beeru, que de tão numerosos e belicosos eram vistos como mais desesperadores do que as formigas? Que de tão mortalmente perigosos não se podia a menos reconhecer neles um inimigo? Um relato de Clastres (1995, p. 40) sobre um grupo de Aché a espreita dos brancos é certamente emocionante:

Os Aché sabiam desde sempre que era preciso se manter afastados das savanas, evitar essas grandes ilhas que de todos os lados a floresta abre, passar ao largo dos descampados infestados de beeru, que não gostavam muito de distanciar. Alguns caçadores audaciosos arriscavam-se no entanto a se aproximar silenciosamente dos grandes abrigos desses seres terríveis. Eles paravam nos limites da floresta; agachados no mato espesso ou empoleirados sobre os galhos baixos de uma árvore, na mão o arco munido de uma flecha pronta na corda, observavam horas a fio, o coração batendo de pavor mas por demais fascinados para deixar tremer o corpo, resignados a morrer mas calculando já a duração do relato que fariam a noite de volta ao acampamento longínquo, antecipadamente impacientes pelas exclamações entusiastas dos homens e soluços das mulheres, mas esperando a cada instante que os beeru desencadeassem seu trovão, eles observavam, prontos a fugir bem diante deles, mais ruidosamente que os tapires, e contudo mais imóveis que a floresta; eles os viam viver, aos poderosos de bizarros costumes.

Da época da escrita da Crônica dos Índios Guayaki (Clastres,1995) não havia se passado mais que 15 anos desde a invasão da terra Aché 
pelo Brancos - semeando ali entre os índios o terror e a morte, forçando-os a nomadizarem-se sobre um espaço que, mesmo sendo vasto, reduzia-se constantemente pelo avanço dos brancos. Inquieto com o avanço mortífero dos temíveis e poderosos beeru de costumes tão bizarros, Jyvukugi se perguntaria (2): “Em qual floresta hei de guiar os Aché se de todos os lados nós cruzamos os caminhos dos beeru?" (Clastres, 1995, p. 40). O que poderia fazer Jyvukugi? O que lhe caberia realizar estando em cargo de um grupo tão pequeno quanto o dos Aché que sofria os efeitos do recente contato com uma multidão de Brancos? Finalmente, Jyvukugi pilharia sozinho um acampamento de lenhadores Paraguaios e munido dos machados e facas que roubou, distribui-os entre todos os homens de seu povo. Revelando-se uma espécie de $\underline{\text { bigmen }}^{5}$ Aché, prestigiado por sua valentia e generosidade, Jyvukugi seria declarado por um de seus pais, Bywangi (ele mesmo um dos "chefes" Aché),: "[...] este será vosso Eruaregi, eis vosso condutor quando eu morrer6 , ele é meu filho, ele é bravo.". (Clastres, 1995)

Daí em diante, o dever de Jyvukugi consistiria, como apontou Clastres, não só em guiar os Aché pelas trilhas de floresta em que abundassem animais de caças, mas, sobretudo, afastá-los tanto quanto for possível dos caminhos dos beeru. Para isso, era preciso deslocar-se sempre sem que se pudesse dormir mais de algumas noites em um mesmo acampamento (mesmo que isso representasse, eventualmente, o risco de não se seguir estritamente as regras que organizavam, por exemplo, os rituais de perfuração labial que simbolizam a iniciação dos meninos Aché). Só assim haveria de "perenar", de permanecer algum tempo, a paz e a tranquilidade entre os Aché. Fazê-lo, contudo, como descreveu Clastres, não foi fácil durante muito tempo: os brancos são multidão, são numerosos e se põem a entrar por toda parte, armados de seu chuvi, seu "trovão", que mata a longa distância e, ao mesmo tempo, na terra indígena roubando-lhes suas crianças. Contra isso, as flechas dos bravos guerreiros Aché não valem coisa alguma e os caçadores com elas não podem contar. Nesse sentido, a multidão de brancos não é outra coisa que uma condenação: os Aché não poderiam esperar deles outra coisa que a morte.

Pois bem. Essas duas falas provindas de Jyvukugi talvez evoquem diretamente o que sugeriu Clastres em "De que riem os índios?" 
(Clastres, 2003, p. 147-166) a partir da exposição de dois mitos de um povo irõiangi dos Aché: os Chulupi (conhecidos hoje como Ashluslay/ Nivaclé), habitantes do Chaco paraguaio. Ao indagar-se a partir deste par de mitos de que caçoam os Chulupi, a primeira conjunção apontada por Clastres mostraria que jaguares e xamãs suscitam o riso dos índios por suas desgraças a que estão sujeitos nos mitos. Mas isso não é tudo. De uma interrogação suplementar sobre a real posição desses seres no pensamento Chulupi, Clastres apontaria que esses seres se avizinham no pensamento indígena menos por sua comicidade do que por sua capacidade de inspirar o medo, o respeito, o ódio, e (curiosamente) nunca a vontade de rir, nos índios (Clastres, 2003, p. 159). Permanecer no riso seria, ao contrário, o que se faz apenas no plano do mito, espaço onde se poderia dar vazão àquilo que, nas palavras de Clastres, é uma "[...] obsessão secreta de rir daquilo que se teme" (Clastres, 2003, p. 162): os Chulupi não ririam, de acordo com Clastres, dos xamãs e dos jaguares reais, pelo fato de não serem nada risíveis, mas respeitáveis e amedrontadores.

Penetra-se, entretanto, um pouco mais na etnografia Chulupi, a fim de refrasear posteriormente a partir das duas falas provindas de Jyvukugi o que apenas já mencionei. De acordo com Clastres, o xamã Chulupi - a exemplo dos xamãs de outras sociedades das terras baixas da América do Sul - é, devido ao seu prestígio e sua autoridade, uma figura ambivalente: é, no mesmo movimento, admirado e temido por sua qualidade de dominar o trato com o mundo dos espíritos e dos mortos. Se o xamã é um sábio capaz de provocar a vida e dominar a morte, ele também é perigoso. É, paradoxalmente, um homem capaz de matar, alvo da desconfiança de todos, sujeito constantemente ao risco da morte, pois sendo responsável pelos acontecimentos extraordinários e pelas relações com o mundo extra-humano, os Chulupi têm medo dele e muitas vezes o matam. Assim, o xamã move-se pelo espaço que lhe é seguro: o espaço distante exterior ao grupo. Se poderia dizer, nesse sentido, que o riso do xamã é sua morte simbólica que o reaproxima do grupo. (Clastres, 2003, p. 160)

Mas assim como os xamãs, os jaguares também são perigosos. Sendo caçadores eficazes e poderosos, os jaguares figuram no pensa- 
mento Chulupi como concorrentes não-desprezíveis nas caçadas das presas cuja predileção repartem com os índios Chulupi: pelos porcos do mato. Nesse sentido, é sempre arriscado topar com algum deles na floresta e sofrer seu ataque. Se os Chulupi, assim como os Aché, exageram o perigo representado por esse animal é apenas pelo fato de, como se exprimiu Clastres (2003, nota VIII), os índios realmente o temerem muito. Assim, os Chulupi sabem apreciar o valor dos jaguares: o respeitam como um igual e, diferentemente do mito, nunca fazem conjugar seu riso com esses animais.

Mas nas falas provindas de Jyvukugi sabemos que o que é dito aterrorizar, fascinar e, algumas vezes, fazer gargalhar os Aché não são apenas os jaguares (ou os xamãs). São também os Brancos matadores de índios, os beeru. E Clastres faz-nos ver ali na Crônica todo o temor e todo o cuidado e empenho de um "chefe" Aché em guardar a distância do Branco, em proteger as pessoas de seu grupo disso que introduz uma disjunção entre a relação a si e a relação a outrem. Para ser Aché é, então, necessário que se persista contra tudo e contra todos. A vida Aché, diria Clastres (1995, p. 118), "permaneceria na fidelidade à sua lei" desde que se pudesse manter afastado o elemento patogênico (os $\underline{\text { beeru) }}$ que sujeita as pessoas desse povo à doença do desespero. Novamente na boca de Jyvukugi, é preciso que os Aché se mantenham na floresta recusando o assédio dos brancos paraguaios - donos dos chovi, "trovões", e da preocupação "cromática" mesclada ao cuidado cristão de "salvar a alma" das crianças Aché,: "Perto dos beeru, os Aché cessa[ra]m de ser Aché. Que tristeza!" (Clastres, 1995, p. 118)

A essa altura, creio que está claro que os brancos são uma dessas figuras como são os jaguares e os xamãs para os Chulupi: formas de alteridade de quem se tem medo, mas ocasionalmente se ri, como se o riso fosse uma espécie de "catarse" da impossibilidade de se rir deles em outro plano que não o do mito, da lembrança do medo de algo que quase aconteceu, ou o da zombaria com um Branco menos perigoso. Ora, o que a evocação das falas provindas de Jyvukugi que precedem sobre o medo e o riso que provocam os Brancos visou explicitar foi uma imagem do pensamento Aché quando em relação com a alteridade fundada em um desejo não-recíproco dos índios de guardar a distância dos conflitos recentes com os Beeru e dos combates com 
eles na floresta - da mesma ordem que o desejo de manter distância das coisas extraordinárias vistas eventualmente por um ou outro homem Aché: uma serpente que por ser grande demais causaria pânico entre as pessoas, a alma ianve dos mortos, ou os seres invisíveis que se divertem debochando dos humanos e tentando agarrar o pênis e raptar os meninos Aché, os kybuchu, para transar com eles. É sem dúvida legítimo afirmar ainda que tal desejo não recíproco dos índios de afastarem-se dos conflitos com essas formas de alteridade os força a pensar (Clastres, 1995). Tudo parece se passar, então, para os Aché como se fosse preciso permanecer sendo Aché 'verdadeiro' e manter a salvo os kybuchu diante das mudanças promovidas em seu espaço pelo avanço dos Beeru (como, por exemplo, a carência de carne de caça ou o plantio de mandioca até então pouco feito pelos Aché nômades). Em outras palavras, aos Aché pareceria necessário manterem-se “verdadeiros" e manter seus filhos a salvo dos brancos quando vulneráveis e expostos a tudo em um espaço diferente e hostil.

Note-se, pois, que o riso e o medo transparecem tanto na etnografia Aché quanto no que escreveu Clastres sobre os Chulupi enquanto reações concomitantes: ri-se, pois se tem medo. Mas talvez uma questão como essa que transparece na etnografia Aché sobre esses "risíveis terrores" nos impila a perguntar se a concomitância do riso e do medo é uma espécie de "traço comum" presente nas etnografias de todos os povos falantes de línguas Tupi ou se, ao contrário, haveria um caso em que o riso e o medo fossem reação não concomitantes? Antecipo que há sim pelo menos um caso em que o riso e o medo não são reações concomitantes. Se abordei anteriormente a etnografia Aché a partir de duas falas provindas de um "chefe" Aché, Jyvukugi, nada melhor do que uma caracterização etnográfica sucinta do tema da alteridade, do riso, do medo e da não simultaneidade e da implicação das duas reações entre os Yudjá realizada a partir de um tema absolutamente arrebatador para as pessoas desse povo: as cauinagens. Como interveio Lima (1995, p. 375), os Yudjá são bastante diferentes conforme estejam embriagados ou não. Se sóbrios, os Yudjá mostram-se discretos, calados e até mesmo tristes e tímidos. Ora, mas isso não significa absolutamente dizer que os Yudjá valorizem algum desses traços. Ao 
contrário, são amantes da alegria exuberante, do riso e das conversas ruidosas, assim como das pessoas expansivas e brincalhonas. O cauim é, então, o que promove a troca da máscara do silêncio, da discrição e do comedimento pela máscara do riso e da desmedida. Cabe, portanto, ao dono do cauim proporcionar ao seu grupo essa espécie de "conversão humoral" mediante a abertura com alarde desse acontecimento, convocando as pessoas para beber de seu cauim.

Bebe-se demais entre os Yudjá. Dá-se que sendo o cauim uma bebida de baixo teor alcóolico, a paixão da embriaguez só se realiza pela ingestão de enormes quantidades de cauim que excedem os nossos padrões. Beber além do limite parece ser, de fato, um valor importante entre os Yudjá. Exceder seus próprios limites é a conduta que se traduz em outros planos da cauinagem, elevando o que quer que se passe ali para a potência. Mas se o traço notável da cauinagem é a alegria que a percorre desde a reunião dos homens, ampliando-se à reunião das famílias nucleares para ser, no fim, dominada e experimentada na forma de um canto ou dança coletiva, sob ela se desenrola uma variedade de afetos. Existe um limiar em que a alegria e o riso de uns torna-se incômodo para os outros e casais começam a reclamar do cônjuge, os pais reclamam dos filhos solteiros pelo fato de estarem bêbados, como se não fosse para estar e como se a embriaguez fosse desonrosa. A verdade é que o cauim, recuperando o que destacou Lima (1995, p. 401), não é uma fonte de alegria sem despertar ao mesmo tempo o ciúme e o desejo sexual ilícito nos Yudjá. Os homem desse povo, segundo disse certa vez uma mulher Yudjá, se interessam muito por uma vagina nova. (Lima, 1995)

Sendo assim, quando vistos de longe os Yudjá revelam-se um bando alegre de bêbados, onde se é lícito dançar, cantar, beber, falar, mas, sobretudo, rir. No entanto, quando vistos a menor distância, esse bando alegre se mostra atravessado por diversos dramas pessoais por causa de sexo pelos quais se chateiam, choram de insatisfação, deprimem-se e confidenciam em pranto seus desejos de ir embora viver entre índios ou, às vezes, de morrer. Nesse sentido, se poderia dizer que tanto quanto a alegria começa a ser minada de fora, por outrem, há um fator suplementar que se liga à lógica da embriaguez que mina o riso 
e a alegria da cauinagem por dentro. Em alguns Yudjá, a embriaguez evolui da alegria para um sentimento indomável cuja "raiva" é o ponto culminante. Na apreensão das pessoas desse povo, são os homens jovens (isto é, os homens que ainda não são avós) que atravessam o limiar e atingem o "cume" desse sentimento, intimidando a todos: eles se lembram de seus inimigos e se mostram, por isso, violentos e com vontade de matar. Em longos monólogos lembram-se de seus antepassados mortos por índios e prometem vingança.

Corpo enrijecido, olhar furioso, gestos bruscos, palavras trôpegas e indelicadas balbuciadas pelo homem em cólera. O bêbado se ofende com as brincadeiras ou com as ironias características da cauinagem ou da recordação furiosa de outras que foram feitas anteriormente. A notícia se propaga em um instante e rapidamente está na boca dos Yudjá: "fulano está bravo!". A música da cauinagem logo cessa e todos acorrem em pânico à casa do cauim repetindo sobre a braveza da pessoa. Os filhos e filhas de um homem amedrontam-se ao ver o pai bravo, outras crianças menores choram de confusão e de medo por não entenderem o que está acontecendo e as maiores fogem com pavor. A esposa fica branca de medo e os pais do homem perdem a cor de suas faces de vergonha do filho embriagado. Ora, mas as razões da raiva do bêbado nunca vem à baila: um homem está bravo porque está bêbado.

O mais interessante é que se, diferentemente do que se viu antes na etnografia Aché, nas cauinagens dos Yudjá o riso e o medo não são reações não concomitantes, não há na transformação do riso e da alegria no medo e na raiva provocada pela embriaguez uma linha que separe aqueles de quem se está com raiva e os outros. Lima (1995, p. 403 ) destacará a partir dessa constatação que a separação é anulada enquanto a raiva é tomada como acontecimento pelos outros. A raiva provocada pela lembrança e pela embriaguez coloca o grupo como um todo no lado de fora do pensamento do homem bêbado e, nesse movimento, a embriaguez não leva à violência contra uma ou outra pessoa, mas contra um "nós" coletivo. O exemplo dado pela autora da etnografia Yudjá (Lima, 1995) é bastante iluminador: a recordação de um homem bêbado do assassinado de seu avô por Índios desperta sua fúria e acaba levando-o a bater em sua mãe que interveio para 
acalmá-lo e levá-lo para casa, assim como em todos que por ventura apareçam em seguida para dominá-lo. A raiva de um outro homem embriagado contra o grupo ou mesmo contra todos de um lado. O grupo coeso protegendo-se da fúria do bêbado, de outro. São as duas cenas que atravessam essa transformação do riso em medo na cauinagem Yudjá.

Mas talvez ao longo de minha exposição desse traço da cauinagem Yudjá, eu tenha deixado de lado (sem que fosse minha intenção e sem que pudesse perceber até agora) um traço suplementar tão importante quanto o que precede, dando ao leitor e à leitora a falsa impressão de que o cauim incide apenas sobre relações sociais e políticas. Devo assinalar (acompanhando uma sugestão de Lima (1995, p. 404) que ao lado do vetor "sociopolítico" da cauinagem Yudjá haveria de existir também um vetor "cosmopolítico" ( sobre o qual não pretendo argumentar, mas tão somente destacar a ambivalência que marca esses momentos que ao suprimirem as explosões de raiva características do vetor sociopolítico, fazem conjugar tanto a alegria quanto a tristeza, tanto o riso quanto o medo) fundamentado na ideia de que o cauim também estimula a relação com o outro mundo (com os animais celestes, com os 1̊ ^ãnay, etc.). Muito bem, mas antes de avançar em direção a etnografia Araweté, penso ser justo trazer à baila um evento suplementar ocorrido com dois homens Yudjá relacionado ao tema do riso e do medo. Passemos, enfim, ao que podemos aprender sobre o mesmo a partir das "gestas" de Mareaji e de Taykapi sobre episódios de doenças que lhes acometeram e algum medo que elas provocaram.

O ano era 1989 e numa tarde de inverno na aldeia Yudjá de Tubatuba uma olhada-de-onça implicaria para Mareaji um período longo de sofrimentos - na noite que sucedeu o encontro com o jaguar, ele sentiu dor no peito, vomitou muito sangue e permaneceu completamente prostrado - e a desconfiança de que provavelmente pegara alguma "doença de animal"" (Lima, 1995, p. 191) e, por essa razão, sua morte se aproximava. O que acontecia é que depois de três dias de caçada coletiva, Mareaji fora informado de que uma onça aparecera em pleno terreiro da aldeia durante o dia. Acompanhado de outros homens para fazer uma busca à onça, encontrou-a, de fato, sossegada em um caminho de roça detrás da aldeia, mas diante da não reação do bicho 
à sua presença, Mareaji desistiu de disparar sua espingarda contra ela, porém, dada a volta à aldeia, o homem quase morreria naquela noite.

Apesar de ter apresentado alguma melhora nos três dias que sucederam o encontro com a onça, Mareaji permaneceu adoentado até outubro daquele mesmo ano, quando optou por seguir até o P.I. Diauarum, a fim de esperar por uma vaga em um avião que o levasse até Brasília. Mas acontece que este "outubro" se transformaria logo em "dezembro" e, nesse interim, Mareaji contraiu malária e pneumonia. Debilitado e aborrecido pela longa espera de um voo até Brasília, Mareaji optou por rumar de ônibus até a cidade, reclamando constantemente da fraqueza de seu corpo e do inchaço em suas pernas. Após um telefonema para a autora da etnografia Yudjá, Mareaji recebeu um convite para ir tratar-se no Rio de Janeiro, mas nem ali seus sintomas desapareceriam. Ao contrário, queixava-se da sensação de peso na cabeça e da vertigem que acompanhava essa sensação, bem como dos calafrios (Mareaji, como conta Lima (1995, p. 193) indagava-se angustiado: "por que estou esfriando? Por que estou esfriando?") e de uma taquicardia, que, segundo ele próprio constatava, eram índices da agitação de sua alma e da proximidade de sua hora de morrer. E isso certamente lhe forçaria a pensar.

Mareaji, como descreveu Lima (1995, p. 192), passou a buscar em cada manifestação do peso a razão que o motivava e a avaliar o que o rodeava no instante da irrupção do sintoma, apontando a partir dessa avaliação uma ou duas razões que justificassem o que lhe acometia. Primeiro, avaliou os alimentos que ingeria, mas, convencido do caráter inofensivo da comida diferente que ingeria no Rio de Janeiro, passou a avaliar as imagens dos livros e revistas, bem como o calor ou a chuva, ou as buzinas e as andorinhas que via pela janela de onde se hospedava. Daí em diante, passaria a avaliar as imagens cinematográficas e televisivas, assim como seus pesadelos - os quais Mareaji julgava não poder contar para não promover a realização da mensagem ruim do sonho.

A angústia de Mareaji, ainda atormentado sete meses após a olhada-da-onça, e sua constante cobrança da razão do peso que sentia em sua cabeça era comovente. Ainda doente em fevereiro do ano seguinte, 
uma médica lhe disse que não havia motivo para preocupar-se, pois estava cheio de sangue (isto é, não estava anêmico), no entanto, uma revelação como essa levou Mareaji a desconfiar que o excesso de sangue em seu corpo devia ser o sangue da onça que fitou e que o fitara e, assim, a solução para por fim à sua doença também parecia revelar-se, no mesmo movimento, diante de seus olhos: precisava se escarificar para derramar fora o sangue do jaguar. Em maio seguinte, quando finalmente retornou a Tubatuba, escarificou seus braços e pernas com a dentadura de peixe-cachorro e daí em diante sofreria ainda duas vezes com o mesmo peso na cabeça, esfriamento e taquicardia, mas se poria de pé novamente, alegre e brincalhão, pouco tempo depois.

Já a história de Taykapi é menor e não envolve nem jaguares, nem brancos. O fato que quero narrar começa com a olhada-de-trairão que, fisgado por seu anzol, lhe jogou uma doença que lhe fez desmaiar a bordo da canoa. Quando voltou a si, o anzol e a linha já tinham sido carregados, a canoa descera acompanhando a correnteza do rio e enrolou um cigarro e o fumou - gesto que, segundo Lima (1995, p. 191), já revelava a sua disposição em não tomar a dor de cabeça que sentia como uma simples doença. Depois do encontro com o trairão, não podia nem ver, nem ser visto por um desses peixes sem sentir-se "embriagado", assim como também não podia comer da carne do peixe. Taykapi haveria ainda de contraefetuar esse acontecimento transformando-se em xamã, atribuindo o episódio com o trairão às forças do cosmos Kayabi, cujo xamanismo é reputado pelos Yudjá provocar doenças ${ }^{8}$.

Essa primeira parte estaria completa caso eu registrasse que entre os Araweté um modo possível da alegria, tori, é a relação de apïhi-pihã (Viveiros de Castro, 1985, p. 423). Cada par de apïhi-pihã de mesmo sexo trata-se em clima de camaradagem jocosa que se põe longe de qualquer conotação agressiva, pois a eles cabe oyo mo-ori uns os outros, "alegrar-se" reciprocamente, e, por isso, estão sempre abraçados, manifestando uma amizade bastante íntima e intensa, sendo companheiros assíduos de trabalho que usufruem livremente dos bens do parceiro. O laço alegre apïhi-pihã é, então, dominante nas expedições coletivas de caça (as mulheres ligadas por esse lado 
dormem na mesma casa); na formação dos dançarinos do cauim e quando atualiza-se em um modo de sexo cruzado (i.e. nas formas de apïhi $(q)$ e apïno $\left.\left(\zeta^{\Uparrow}\right)\right)$ chamam-se de tori-pã, "alegradores".

Ora, mas o que subjaz ao "objetivo" dessa relação? O que constatou Viveiros de Castro ( 1985) foi que o cimento da relação de apïhi-pihã é a mutualidade sexual que se efetua como uma troca temporária de cônjuges segundo dois métodos distintos. Um deles, oyo iwi, "morar junto", pelo qual os homens vão a noite para a casa de suas apïhi retornando na manhã seguinte para sua situação conjugal. Já no segundo, oyo pepi, "trocar", as mulheres passam a residir temporariamente nas casas de seus apïno. Seja qual for o caso, o quarteto de apïhi-pihã é sempre visto junto no pátio de um dos casais. Caça, dança, pintura, sexo, canto e perfume são os elementos que compõem seu mundo ideal de mutualidade que se concebe em espelho ao mundo celeste e a relação entre os deuses e as almas dos mortos. No fim, se poderia dizer ainda que a mutualidade sexual que caracteriza o sistema apïhi-pihã - cujo lugar privilegiado de efetuação é a mata durante as estações de coleta de mel, os acampamentos de caça e o período de amadurecimento do milho - é uma alternância de contatos sexuais com os dois outros do sexo oposto. (Viveiros de Castro, 1985)

O tema excluído do sistema apïhi-pihã é, como se poderia imaginar, o ciúme 9 , haihï, envolvendo, precisamente, o seu oposto: a cessão entusiasmada do cônjuge ao parceiro e ter apïhi-pihã é visto entre os Araweté como índice de maturidade social, generosidade, alegria, força vital e prestígio, mas também é, sem dúvida, mais do que isso. Ter um parceiro apïhi ou apïno é uma conquista sobre o território dos não parentes, dos Tiwã, uma abertura ao Outro que opera via o estabelecimento de uma identidade onde só havia anteriormente não relação. Lê-se ainda em Viveiros de Castro (1985, p. 427) que talvez entre os Araweté o casamento figure menos como o procedimento para se conseguir um cônjuge que o evento necessário para se ter acesso a um casal que duplique e 'idealize' a própria relação conjugal. Se assim, um apïhi-pihã é um antídoto para a afinidade, ou ainda, para recompor o que disse o autor da etnografia Araweté, "síntese ideal do "eu outro" - o $\underline{\text { anĩ }}$ - e do "outro eu" - o tiwã.." (Viveiros de Castro, 
1985). Para falar com a boca dos Araweté, um quarteto de apïhi-pihã se "entrecome", $\underline{\text { oyo o }}$, e isso, de fato, não é pouco, pois se entrecomem sexualmente, esse fato talvez seja também aproximável com a "síntese canibal" colocada pela antropofagia e com o ideal do incesto.

Uma pergunta se coloca imediatamente. De onde são recrutados os ap̈̈hi-pihã de um casal? Por definição, dos Tiwã, isto é, são recrutados da periferia da parentela de Ego. Um apïhi-pihã é, quase sempre, parente de afins ou um parente classificatório em posição de afinidade potencial (por exemplo: um ZHB, MZBS ou WMZDH). Em poucas palavras, são vindos do mesmo lugar de onde vêm os afins, donde se poderia sugerir que um apïhi-pihã é um "anticunhado" (Viveiros de Castro, 1985, p. 430), pois se meu cunhado é, por definição, um afim ligado a mim pela inacessibilidade sexual de meu sibling a mim; o que define a relação de apïhi-pihã é, por outro lado, a mútua acessibilidade sexual dos cônjuges. Mas isso não é tudo, porque se um apïhi-pihã é um anticunhado, ele também revela-se uma espécie de "anti-irmão", pois, acompanhando uma nota de Viveiros de Castro (1985), a equivalência de dois irmãos (marcada, devo salientar, pelo medo e pela evitação) diante das mesmas mulheres é anterior à existência delas - fazendo da mútua acessibilidade sexual às esposas uma consequência desse fato - no sistema apïhi-pihã, o laço conjugal precede a equivalência entre as apïhi ou os apïno.

Ora, podemos assim afirmar que o sistema apïhi-pihã faz explícita a necessidade de afinar nosso vocabulário, pois o átomo do parentesco Araweté se apresenta mais complexo do que o modelo clássico lévi-straussiano. Um pouco como disse Viveiros de Castro (1985, p. 433), o sistema apïhi-pihã incorpora ao modelo de parentesco de Lévi-Strauss "antipartículas" e um princípio de incerteza: a relação de antiafinidade. Mais ainda, o sistema apïhi-pihã coloca diante de nós a imagem de um sujeito que mais do que um irmão, é um síncrono, um equivalente não ambivalente de uma pessoa. É, em suma, um "terceiro incluído", "o Outro miraculado em duplo" (Viveiros de Castro, 1985, p. 434) que só é obtido mediante a obtenção de uma esposa que, por seu lado, só é obtida mediante uma operação cronologicamente anterior: ter como parente uma irmã. Mais uma palavra sobre essa recusa da afinidade. Todo o sistema Araweté milita em favor desta que, sendo impossível, 
não é menos efetiva: há entre as pessoas desse povo uma proliferação de casamentos oblíquos, de redundância de alianças, fechamento de parentelas, dispersão de reciprocidade que vai ao encontro e se mistura com a proliferação de laços de antiafinidade. O riso e a alegria que marcam as relações de apïhi-pihã se entendem, creio, como efeitos da tentativa obstinada de burlar o limite do social, isto é, da interdição do incesto e da reciprocidade. Para finalizar sobre o riso e a alegria, devo dizer que são frutos de uma escolha. A escolha de abrir-se ao fora, a escolha de "[...] em vez de evitar os cunhados, frequentar os amigos [apïhi-pihã]". (Viveiros de Castro, 1985, p. 435)

Pois bem. Mas talvez seja preciso retomar a questão do riso e do medo, a exemplo das interrogações que nortearam anteriormente as visadas sobre as etnografias Aché e Yudjá. Como se viu anteriormente, poder-se-ia aproximar o riso dos apỉhi-pihã do riso dos Yudjá nas cauinagens, na medida em que, diferentemente dos Aché, o riso dos Yudjá e dos Araweté nas situações que mencionei não é um riso "dos outros", mas sim um riso com "os mesmos", isto é, com aqueles que são ou amigos ou parentes. Mas teria o riso dos quartetos de apïhi-pihã a mesma potência do riso desmedido e embriagado pelo cauim entre os Yudjá? De certo que não. Entre os quartetos apīhi-pihã dos Araweté exclui-se o ciúme, visto que esse só existe como possibilidade de turvar a alegria com a violência transformando, portando, o próprio riso em medo.

Muito bem. Tomemos rapidamente então uma via cosmopolítica complementar à via sociopolítica do sistema apïhi-pihã para terminar esta primeira parte. A partir de uma sugestão de Viveiros de Castro, poder-se-ia dizer que se a alegria e o riso, ao lado da mutualidade, são os motes das relações de antiafinidade; o "medo-vergonha", čiye, é o tema principal da relação entre os Araweté e os espíritos terrestres $\underline{\tilde{A} \tilde{n}}^{10}$ e seus congêneres, ou das pessoas desse povo com os deuses Mai que sendo tanto ipoïhi, "extraordinários" e "esplêndidos", quanto amedrontadores e estranhos, impõem medo e respeito aos xamãs que, temerosos, sempre cambaleiam quando os veem. Não são reações de se espantar, de fato. Os Maï são, segundo os Araweté, deuses canibais mais perfeitos do que os humanos - que são apenas cópias pálidas dos 
seres celestes - e apresentam um esplendor de vida que lhes transformam em hipérboles dos padrões ideais de beleza e de xamanismo dos humanos vivos. Diferentemente dos deuses Maï, os Ãñĩ são tidos pelos Araweté, por outro lado, como seres necrófagos que banqueteiam-se com a carne dos mortos e fazem flautas com suas tíbias. São verdadeiramente inimigos, awĩ bárbaros, selvagens e assassinos dos humanos vivos que moram no oco das árvores, são fedorentos e atormentam os Araweté ao lhes sujeitarem constantemente ao risco de terem suas almas ou suas crianças raptadas. É aqui, logo, que reencontramos a presença do medo. Se o medo passa pela relação dos Araweté com os Maï no reconhecimento da potência canibal deles com os mortos, por outro lado, o medo dos Ãñĩ se deve ao fato de eles serem fonte de inúmeros infortúnios aos Araweté vivos.

Mas mesmo não sendo nem "donos de animais", nem "donos da mata", os Ẫñ̃ mantém uma relação privilegiada com a animalidade. São, na realidade, afins de várias espécies de animais e, a exemplo deles, os $\underline{\text { Ãñ }}$ também não são hukāy pa, isto é, não habitam aldeias como os humanos ou os Maï. Ora, mas isso não corresponde absoluta-

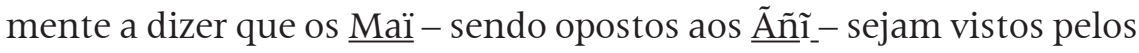
Araweté como heróis culturais ou civilizadores, pois, como destacou Viveiros de Castro (1985, p. 220), eles evocam uma primitividade essencial (eram leigos do uso do fogo e das plantas cultivadas) expressa num estranho epíteto que joga luz sobre sua natureza selvagem. Os Maï são me'e wi a re, "os comedores de carne crua" ${ }^{11}$ e são, portanto, "extraculturais", pois evocam, no mesmo movimento, o fundo arcaico da humanidade mas apontam para um futuro da boa existência, da exuberância e da superabundância.

\section{Do Lado de Fora de Mim, do Lado de Fora do Mundo}

É chegada a hora então de enfrentar uma questão mais ou menos difícil, difícil inclusive de ser colocada. Ela remete ao que Gilles Deleuze trouxe à baila em Imagem-Movimento (1983) em um comentário sobre a filosofia de Bergson sobre a ideia de que cada homem é constituído por um esquema sensório-motor que lhe permite reagir a situações e a eventos no mundo, bem como lhe permite apreender o movimento 
que vem de fora por meio de uma estrutura sensória e prolongá-lo, e devolvê-lo, no mesmo golpe, para o mundo. Mas há algo mais. Acontece que no caso humano haveria uma espécie de "descolamento" (ou um intervalo...) entre a via sensória e a via motora que impediria que uma sensorial se prolongasse em uma estrutura motora. Ademais, devo salientar que é neste intervalo entre as duas estruturas que estariam os afetos e as afeç̧ões ${ }^{12}$ que, em conjunto com a percepção (esta tomada como captura pelo esquema sensório-motor do movimento que vem do exterior) formam um esquema tal que permitiria que as pessoas humanas apreendessem os movimentos vindos do exterior e acionassem a partir dessa captura seus próprios movimentos. O ponto aqui é, então, justamente que tal bloqueio do prolongamento da via sensória na via motora abrirá espaço, como argumentou Deleuze, para o surgimento do tempo no cinema.

Pois bem. Que se pergunte, portanto: o que provocaria esta ruptura do esquema sensório-motor? Ou, ainda, o que é que promoveria essa quebra de vínculo com o mundo que faz sair do campo de ação e transformar-se num "vidente" e quais seriam os efeitos dessa "quebra"? A ideia que Deleuze teve a partir do cinema, particularmente em sua análise sobre o neorrealismo Italiano ${ }^{13}$, foi a de que o enfraquecimento e a quebra são provocadas por interiores vazios, paisagens vazias, tão semelhantes quanto as do Europa do período pós-guerra: situações que excedem a percepção humana, levando a disjunção de porções do espaço, o acaso torna-se o único fio condutor e substitui-se a ação pela errância, pela perambulação, pela ida e vinda contínua - fruto de uma necessidade interior ou exterior, uma necessidade de fuga de um mundo sem totalidade nem encadeamento. Ora, mas o que é que 'cimentaria' esse mundo repleto de situações dispersivas e de ligações deliberadamente frágeis? Os clichês, e nada mais. Diz Deleuze (1983, p. 232): "[...] clichês, clichês por todo lado [...]". O que não é menos notável é que o colapso daquilo que Deleuze nomeou de "imagem-ação" (diretamente ligada ao esquema sensório-motor) característica do realismo, deixaria emergir lugares nos quais se desenvolveriam tanto os afetos do medo, quanto os do frescor e do riso. Tanto de uma velocidade extrema, quanto os de uma espera interminável. 
Não gostaria de esconder que a observação de Deleuze sobre o desmonte de uma situação sensório-motora diante de uma paisagem que excede a percepção de um sujeito colocou-me por algum tempo num estado de inquietação e me levou a indagar, após ler especificamente o texto de uma conferência Pelbart (2000) em que este autor evoca o nome de Deleuze e de Maurice Blanchot em favor de uma meditação sobre o que chamou de paixão pelo/do "fora", se um aspecto importante desse mundo sem totalidade e encadeamento marcado pela disjunção de porções do espaço e proliferação de clichês provocada pela ruptura do esquema sensório-motor não seria justamente sua ligação com uma dimensão exterior que, a exemplo do que sugeriu Deleuze para o pensamento no cinema, está em uma relação absoluta com ele. Caso assim, levando-se em conta o que ponderou Pelbart sobre a relação da filosofia de Deleuze e a dimensão do fora (dehors), se o pensamento não é uma faculdade inata, mas o efeito de um encontro com uma dimensão exterior - ainda que esta realmente não corresponda à configuração empírica do mundo, mas às forças heterogêneas que afetam o pensamento e o colocam em um "estado de exterioridade" e forçamno a pensar - seria possível sugerir nesse caso que o que introduz a "desarticulação" no mundo é também a inserção de um intervalo na capacidade de perceber e agir um espaço aberto de liberação de forças, delineando, nesse movimento, um mundo de resistência a um estado de coisas em que a própria força do fora é uma espécie de impulso de vida? (Pelbart, 2000, p. 206)

Diante de uma operação de conciliação que me pareceu muitas vezes difícil de fazer, a nota de Åkervall (ela também está pensando a partir do cinema) contribuiu com alguma luz sobre o que perguntava. Se o modo característico de um mundo marcado pela proliferação de situações óticas e sonoras surgidas do confronto com algo que ao se revelar poderoso demais excede a capacidade do esquema sensóriomotor é o da "quase-ação", então se poderia dizer que o mesmo forçar o cinema a pensar uma nova brecha para o pensamento que se expressa numa nova forma de ver (que é, na realidade, a interligação de uma amplo conjunto de faculdades) ligada, por seu lado, à um excesso de experiência e de percepção. Uma nova visão (ou um novo pensamento) 
que é regida por um exercício de elevar a visão ao seu grau mais alto e substituir um modelo "recognitivo" (fortemente ligado ao esquema sensório-motor) por um modelo "cognitivo", em que não se reage mais ao um encontro com forças heterogêneas, mas se $v \hat{e}$ neste encontro. $\mathrm{O}$ que articula a diferença entre os dois modelos é, então, o fato de que ver num encontro como esse estaria sempre ligado ao imperativo de fazer emergir uma nova conexão entre os humanos e o mundo ao seu redor.

Mas como mencionei nas páginas que precedem, a natureza do meu problema neste ensaio não é exatamente cinematográfica e minha intenção retornando às notas de um filósofo como Gilles Deleuze não foi senão a de estabelecer uma relação de vizinhança entre elas e algumas elaborações do pensamento ameríndio sobre o contato com a alteridade radical expressas na forma do riso ou do medo. Uma diferença já é, antecipadamente, fundamental. O que diverte ou aterroriza os índios e coloca o seu pensamento em "exterioridade" não é, exatamente, uma situação "sobrenatural" que se revela a eles estranha demais. Ao contrário, o que pode fazê-los enxergarem-se em um mundo sem encadeamentos é, muitas vezes, um excesso de "cotidianidade" que esconde por trás de suas aparências um acontecimento que "quase-provocará" a morte (mesmo quando ela não corresponde à morte "de fato") de uma pessoa. Nesse sentido, todo o meu problema e minha hipótese se poderiam então formular assim: o riso e o medo provocados pelo contato com seres definidos por sua alteridade radical (que não raramente se revelam poderosos demais por debaixo de sua aparência normal) - que também se revela um desejo igualmente radical por parte do Eu. Todo o problema é então que estas situações cujo modo prevalecente de ação seria o da "quase-ação" e que ao exceder a percepção parecem colocar o pensamento em um estado de exterioridade (ou ainda, provocam uma espécie de "abertura ao Outro") também implicam, como pode-se ler em Viveiros de Castro (2012), na inclusão do outro (ou pelo outro) como forma de perpetuação do devir-outro - um processo do desejo, como definiu este autor, característico das socialidades amazônicas.

Creio estar nítido que o problema desse ensaio e sua hipótese viram-se facilitados pela análise da sociocosmologia dos grupos Tupi realizada por Viveiros de Castro (1986), sobretudo por suas genera- 
lizações e hipóteses a respeito de um "método Tupi-Guarani"14 de constituição da pessoa que, diante de sua estrutura social frouxa e casual; ausência de fronteiras claras entre o socius e o cosmos; aparente fragilidade ao contato com a sociedade ocidental, seguiria uma tendência não euclidiana que se efetuaria - a diferença das propriedades cristalinas reputadas aos grupos falantes de línguas Jê - menos por meio de uma pulsão estabilidade de forma, ou através de um jogo de reflexões e inversões entre Eu e Outro, que por um processo contínuo de deformação topológica onde Eu e Outro estão aquém ou além da representação, movendo-se num universo onde, diz o autor, o devir antecede (e se mostra insubmisso, no mesmo golpe) ao ser e arriscando um método de dupla afirmação: isso e aquilo; Eu e Outro, ao invés de Eu ou Outro.

Eis que há pouco eu falava em riso e medo de índio e agora invoco notas tanto sobre a relação com a alteridade quanto sobre eventos que forçam o pensamento a pensar ao colocá-lo em "exterioridade". É que nenhuma das duas evocações aparece separada no pensamento indígena, pois se é verdade que sem o influxo das forças vinda de fora do socius ameríndio, ele finda por falir por "carência de diferença" (Viveiros de Castro, 1985), não é menos verdadeiro que as experiências cotidianas como o contato com os Brancos, as cauinagens, os sistemas de relações de antiafinidade, absolutamente aterrorizantes e hilariantes em sua aparente "normalidade", também forçam o pensamento ameríndio a pensar maneiras de controlar esse fluxo e capturar essas potências sem que se deixe desumanizar por elas. Teme-se ou ri-se, então, por um problema que do ponto de vista de nosso entendimento do pensamento ameríndio é o seguinte: como "viver bem" (como os próprios índios gostam de dizer) em um mundo em que a alteridade radical opera enquanto condição transcendental vivida? Quase sempre será então o parentesco que funcionará como máquina capaz de conter esta ameaça molecular, epítome do riso e do medo, vinda de fora contra a humanidade de uma pessoa, isto é, como uma máquina de captura de identidades e potências vindas do exterior do grupo, pois a humanidade seria concebida como uma posição continuamente produzida em um universo habitados por outros centros de agência 
não humanos. Reencontramos aqui, então, uma dimensão exterior do socius ameríndio e o que ela faz ressoar no pensamento indígena, uma vez que o que a experiência do parentesco entre os povos Tupi revelaria seria a articulação entre grupos de parentes e formas de alteridade que povoam mundos divergentes expressa num jogo complexo de alianças e captura de forças vindas de fora do cosmos indígena.

Mais uma palavra, ainda, a guisa de conclusão. Se me pareceu existir uma zona de vizinhança produtiva entre a ressonância produzida no pensamento de Gilles Deleuze a partir do encontro de suas reflexões sobre o cinema com seus comentários sobre a dimensão exterior do pensamento, e algumas situações retiradas da etnografia de povos falantes de línguas Tupi que provocam o riso ou o medo nos índios, presumi que Deleuze teria algo mais a nos dizer sobre os acontecimentos que findam por colocar o pensamento num estado de exterioridade em um contexto outro que não o cinematográfico, e busquei tornar mais manifesta a atenção para as potências que se abrigariam, segundo a etnografia Amazônica, fora do socius indígena. Longe de mim, porém, a ideia de que seria possível arrastar mecanicamente tais potências para o "interior" do pensamento de Deleuze: proponho apenas que estas situações retiradas da etnografia sobre povos indígenas da América do Sul sobre acontecimentos que provocam o riso e o medo nos índios também colocariam o pensamento em um estado de exterioridade.

Creio, em todo caso, que Deleuze não recusaria o estabelecimento de uma zona de vizinhança como essa, uma vez que bem soube colocar mais de uma vez com tanto rigor o problema de como fazer com que imagens do pensamento pudessem ser apresentadas ao longo de uma história de maneira coincidente com a própria história da filosofia. Ademais, minha pretensão não foi aqui também reduzir a inquietude com o fora expressa na forma do riso ou do medo pelos índios à uma pretensa influência da filosofia de Gilles Deleuze no pensamento ameríndio. A ideia sendo aqui que o riso e o medo provocados pelo contato com seres definidos por sua alteridade radical, índices da presença daquilo que excede a percepção humana, parecem colocar o pensamento em um estado de exterioridade (ou ainda, provocam uma espécie de "abertura ao Outro"), assim como também parecem impli- 


\section{car, como pode-se ler em Viveiros de Castro (2012), no pensamento sobre a inclusão do outro (ou pelo outro) como forma de perpetuação de um devir-outro, característico das sociocosmologias ameríndias.}

\section{Notas:}

1 Possui graduação em Ciências Sociais pela Universidade Federal do Espírito Santo; Mestrado em Antropologia Social pela Universidade Federal Fluminense e é doutorando em Antropologia Social pela mesma instituição. Tem interesse na área de Etnologia Indígena, em particular nos sistemas sociocosmológicos ameríndios e suas transformações na Amazônia e no Chaco Paraguaio. Endereço: Av. Presidente Café Filho, 475. BNH, Linhares - ES. 29902400.

2 Gostaria de ressaltar que foi Sztutman (2005) quem teve a ideia de introduzir o tema de uma "cosmopolítica" na pauta da Etnologia Indígena contemporânea.

3 Penso ser importante frisar aqui, acompanhando uma intervenção de Åkervall (2008), que esta dimensão 'intolerável' não é absolutamente redutível à divisão "ordinário/extraordinário", podendo remeter, ao contrário, tanto a um quanto ao outro.

4 Se notará aqui que o emprego do termo chefe entre aspas simples deve-se ao fato de que nem a chefia enquanto instituição política ameríndia se exerceria por meio da coerção, nem o chefe indígena figuraria, sob o risco da recusa dos índios em aceita-lo como tal, como o homem cujas ordens devem ser obedecidas por todos. Ao contrário, o chefe Aché, devoto a uma filosofia política 'selvagem' que separaria fortemente o poder da violência, seria, segundo Clastres (2003, p. 67), aquele que faria desdobrar sua autoridade no que mais se opõe ao elemento opressivo comum à filosofia política dos Brancos: o elemento discursivo encontrado em sua palavra.É aí que repousaria a prova da 'dignidade' da chefia de Jyvukugi: fazer equivalentes a lei dos Aché Gatu e a lei de seu próprio desejo de ser seu beerugi, seu chefe.

5 Para um desenvolvimento mais vigoroso e interessante da noção de bigmen em um contexto não Oceanista e sua diferença com a noção de chief, ver Sztutman (2005). Registre-se também que nesta divisão que Marshall Sahlins (1963) criou para a Oceania, apenas os chiefs seriam líderes políticos autoritários que baseariam seu poder na forte hierarquização da sociedade, bem como no acúmulo de riquezas e num acentuado complexo ritualístico. As sociedades de bigmen, diferentemente, seriam sociedades "igualitárias" em que um homem ou uma classe de homens não poderia se apropriar da produção dos demais homens. Assim sendo, a Melanésia de Sahlins resultaria em sistemas políticos incipientes, constituídos por blocos políticos pequenos, separados e equivalentes, dotados de autonomia econômica e sustentados por cultos masculinos contrastaria com o caso Polinésio, palco para diversas chefaturas distintas do sistema tribal melanésio tanto pelo tamanho das unidades sociopolíticas quanto pelo esquema piramidal dessas chefaturas que pressuporiam valores diferentes para as linhagens.

6 Segundo nos informa Clastres, Bywangi morreria pouco tempo depois durante um embate com os Brancos.

7 Para os Yudjá estas "doenças de animais" são contraídas por ocasião de um confronto com um animal. Nestas situações, os Yudjá sustentam que os animais os dão "sua própria doença". É importante ressaltar ainda que os Yudjá não articulam essas doenças a nenhum animal específico. Ver Lima (1995, p. 191). 
8 É importante lembrar, em todo caso, que adoecer não é uma dessas palavras que traduziriam a concepção dos Yudjá sobre acontecimentos como os ocorridos com Mareaji e Taykapi. Como observou Lima (1995, p. 188), na boca dos Yudjá há apenas a palavra doença, kana?ua, para designar algo que existe apenas no mundo exterior. Nesse sentido, a doença é para os Yudjá algo que sempre vem de fora, podendo ser extraída por um xamã. O que não é menos interessante é o fato que para os Yudjá raramente alguém fica doente de apenas uma doença: cada sintoma corresponde a uma doença distinta, cada manifestação de um sintoma pode ser provocado por um agente distinto. Em poucas palavras, para me servir do texto de uma feliz sugestão de Lima (1995), “[...] o que consideramos uma doença, os Juruna [Yudjá] consideram uma multiplicidade". Mas talvez ainda seja preciso destacar que os Yudjá não encerram a economia das doenças em um sistema fechado. A predação a que está sujeito um homem não existe, segundo os Yudjá, apenas como um prolongamento da predação que ele próprio exerce, isto é, a teoria Yudjá sobre as doenças transborda os limites da teoria da ação humana tal como concebida pelas pessoas desse povo, baseada, a saber, na premissa de que a alma de uma presa/objeto liga-se ao predador e permanece ativa, exercendo sua força característica sobre um doente. Este fato, de acordo com uma intervenção de Lima (1995, p. 194), seria apenas um aspecto particular de uma concepção mais ampla de que o que quer que haja no mundo pode ou cair sobre ou projetar algo de si sobre os Yudjá.

9 Entre os Araweté o sistema apïhi-pihã é a única situação sexual extraconjugal que envolve o oposto do ciúme. Ver Viveiros de Castro (1986, p. 425).

${ }^{10}$ Não seria correto dizer, contudo, que a relação entre os humanos e os Ẫñ̃ pauta-se apenas no medo. Entre os Araweté há também aqueles que afirmam que os $\underline{\tilde{a} \tilde{n} i}$ são menos temíveis que desprezíveis.

${ }^{11}$ Noção que se aplicaria, hoje, aos jaguares.

12 Sobre a especificidade do uso do termo "afecção" na obra de Gilles Deleuze para designar as capacidades de um corpo de agir e de ser afetado pelas ações de outrem, recomendo a leitura do guia e glossário organizado por Mark Bonta e John Protevi (2004).

13 É importante salientar, como bem soube notar François Dosse (2010), que o fato de Deleuze ter enxergado no neorrealismo italiano a primeira experiência de colapso da imagem movimento não se deveu a uma escolha arbitrária. Dado a fim da Segunda Guerra, a Itália encontrava-se em uma situação bastante ambígua: o governo italiano havia se aliado a Alemanha nazista, mas a população do país se levantou contra os regime facista. Foi em um contexto "perigoso", para usar o termo que o próprio Dosse se serviu para caracterizar este cenário, que o novo cinema de Rosselini, De Sica e outros fizeram colapsar o cerne da imagem-movimento.

14 Sobre o uso do termo Tupi-Guarani de forma generalizante é importante salientar o seguinte: os Yudjá não são falantes de uma língua dessa família (ainda que sua cultura os aproxime da cultura dos outros povos falantes desta). Os Aché, mesmo falantes de língua Tupi-Guarani, praticavam um endocanibalismo funerário que se afastaria do exocanibalismo característico de uma forma proto-tupi. 


\section{Referências}

ÅKERVALL, Lisa. Cinema, Affect and Vision. Rhizome 16, summer, 2008. Disponível em: <www.rhizomes.net/issuel6/akervall.html>. Acesso em: $1^{\circ}$ jul. 2012.

BONTA, Mark; PROTEVI, John. Deleuze and Geophilosophy: a guide and glossary. Edinburgh: Edinburgh University Press, 2004.

CLASTRES, Pierre. Crônica dos índios Guayaki: o que sabem os Aché, caçadores nômades do Paraguai. São Paulo: Editora 34, 1995.

CLASTRES, Pierre. De que riem os índios? In: . A sociedade contra 0 Estado. São Paulo, CosacNaify, 2003.

DELEUZE, Gilles. A Imagem-Movimento. São Paulo: Brasiliense, 1983.

DELEUZE, Gilles. A Imagem-Tempo. São Paulo: Brasiliense, 1990.

DELEUZE, Gilles; GUATTARI, Félix. Qu'est-ce que la Philosophie? Paris: Minuit, 1991.

DOSSE, François. Gilles Deleuze and Félix Guattari: Intersecting Lives (European Perspectives: A Series in Social Thought and Cultural Criticism). Columbia: Columbia University Press, 2010.

LIMA, Tania Stolze. A parte do Cauim: etnografia Juruna. Tese (Doutorado em Antropologia Social). Rio de Janeiro. Universidade Federal do Rio de Janeiro, 1995.

LIMA, Tania Stolze. Um peixe olhou para mim: o povo yudjá e a perspectiva. São Paulo: Edunesp, 2005.

PELBART, Peter Pál. The Thought of the Outside, the Outside of Thought. Angelaki, v. 5, n. 2, p. 201-209, 2000.

VIVEIROS DE CASTRO, Eduardo. Araweté: os deuses canibais. Rio de Janeiro: Jorge Zahar, 1986.

VIVEIROS DE CASTRO, Eduardo. Immanence and fear Stranger-events and subjects in Amazonia. HAU: Journal of Ethnographic Theory, 2 (1): 27-43, 2012.

Recebido em 16/12/2012

Aceito em 23/08/2013 